\title{
ИСПАРИТЕЛЬНО-КОНДЕНСАЦИОННЫЕ СИСТЕМЫ ОХЛАЖДЕНИЯ ЭЛЕКТРОННОЙ АППАРАТУРЫ
}

\author{
А. Н. ГЕРШУНИ, А. П. НИЩИК \\ Национальный технический университет Украинь \\ «Киевский политехнический институт им. Игоря Сикорского», \\ Украина, Киев, 03056, пр-т Победы 37
}

\begin{abstract}
Аннотация. В статье показано, что тепловые трубы с металловолокнистыми капиллярными структурами и испарительно-конденсационные системы охлаждения на их основе являются высокоэффективными средствами обеспечения оптимальных тепловых режимов различных приборов и устройств электронной техники. Такая система охлаждения, совмещая функции эффективного теплопровода (эквивалентная теплопроводность намного выше теплопроводности наиболее теплопроводных материалов) и эффективного радиатора с возможностью пассивного теплоотвода, характеризуется высокой теплопередающей способностью, низким термическим сопротивлением, относительно малыми габаритами и массой, надежностью работы при различной ориентации в пространстве в условиях действия массовых сил. Описаны примеры выполненных разработок и исследований тепловых труб и испарительно-конденсационных систем с металловолокнистыми капиллярными структурами для охлаждения различных тепловыделяющих объектов электронной техники. При этом рассмотрены в основном специальные типы и конструкции систем, работающие при различных условиях теплоотвода к поглощающей среде, в том числе обладающие не только высокой теплопередающей способностью, но и специфическими диэлектрическими свойствами. Приведены теплотехнические характеристики предложенных систем охлаждения.
\end{abstract}

Ключевые слова: тепловые режимы аппаратуры; испарительно-конденсационные системы охлаждения; специальные типы и конструкции; тепловые характеристики

\section{1. ОБОСНОВАНИЕ АКТУАЛЬНОСТИ}

Функционирование элементов аппаратуры в заданных температурных интервалах позволяет получить оптимальные рабочие характеристики и увеличить время их безотказной работы. Постоянное совершенствование электронной аппаратуры (ЭА), ускоряющееся развитие компьютерной техники приводят к увеличению теплонапряженности таких элементов, как микропроцессоры, сверхвысокочастотные полупроводники и др. [1]. Современные тенденции развития ЭА, включающие миниатюризацию аппаратуры, приводят к уменьшению массогабаритных характеристик с со- ответствующим увеличением плотности выделяемых тепловых потоков и температуры.

Температура является основным фактором, влияющим на надежность аппаратуры. При увеличении температуры надежность резко падает, обычно нормальное функционирование приборов нарушается при ее повышении до $85-150{ }^{\circ} \mathrm{C}[2]$ в результате нарушения режимов работы, увеличения диэлектрических потерь и токов утечки в изоляционных материалах, снижения прочности изоляции и вязкости пропиточных материалов.

Использование традиционных систем охлаждения (CO) может привести к перегреву и

DOI: $10.20535 / \mathrm{S} 0021347017070044$

(c) А. Н. Гершуни, А. П. Нищик, 2017 


\section{БИБЛИОГРАФИЧЕСКИЙ СПИСОК}

1. Шматов, Д. П. Моделирование процессов гидродинамики и теплообмена в микроканальных элементах систем охлаждения электронной аппаратуры / Автореф. дис. ...канд.техн.наук. : Воронеж, Воронеж. гос. тех. ун-т. - 2011. — URL : http://www.dissercat. com/content/modelirovanie-protsessov-gidrodinamiki- iteploobmena-v-mikrokanalnykh-elementakh-sistem-okhl

2. Сушко, В. Ю. Тепловая защита электронных устройств при интенсивных термических воздействиях / Автореф. дис. ... канд. техн. наук. : С.-Пб., С.-Петерб. гос. ун-т информац. технологий, механики и оптики. - 2007. - URL : http://www.dissercat.com/ content/teplovaya-zashchita-elektronnykh-ustroistv-priintensivnykh-termicheskikh-vozdeistviyakh.

3. Ермолаев, И. А. Математические модели и методы исследования конвективных потоков жидкостей и газов в системах охлаждения устройств радиоэлектроники / Автореф. дис. ...докт. физ. мат. наук. - Саратов, Сарат. гос. ун-т им. Гагарина Ю.А. - 2013. URL : http://www.dissercat.com/ content/ matematicheskie-modeli-i-metody-issledovaniya-konvektivnykhpotokov-zhidkostei-i-gazov-v-sis.

Поступила в редакцию 14.06.2016
4. Цевух, И.В.; Спивак, В.В.; Малюта, А.И.; Шуба, Т.Н. Система управления тепловыми режимами электронных приборов. Технология и конструирование в электронной аппаратуре, № 1, С. 20-22, 2016. DOI: $10.15222 /$ TKEA2016.1.20.

5. Исакеев, А.И.; Киселев, И.Г.; Филатов, В.В. Эффективные способы охлаждения силовых полупроводниковых приборов. Л. : Энергоиздат, Ленингр. Отд., 1982. 298 с.

6. Дульнев, Г.Н.; Тарновский, Н.Н. Тепловые режимы электронной аппаратуры. Л.: Энергия, 1971. $-248 \mathrm{c}$.

7. Akhil, Soman; Anu, Nair P., RemilBabu; SambathKiran, P. K.; Sumesh, V. S. Study on natural convection heat transferin an enclosure - A review. J. of Mechanical and Civil Engineering, Vol. 13, No. 4, P. 26-30, 2016. DOI: 10.9790/1684-1304062630.

8. Полушкин, А. В. Влияние конструктивных параметров системы кондуктивного охлаждения на температурный режим радиоэлектронной аппаратуры в герметичном корпусе / Автореф. дис. ... канд. техн. наук. С.-Пб., С.-Петерб. гос. ун-т информац. технологий, механики и оптики. 2007. URL : http://www.dissercat.com/ content/vliyanie-konstruktivnykh-parametrov-sistemy-konduktivnogookhlazhdeniya-na-temperaturnyi-rez.

9. Gallefoss, Helge. Патент WO 2013056823 A1. A device and a method for passive cooling of electronic equipment. МПК Н05К 7/20 (2006/01). Дата публикации 25 апреля 2013 г.

10. Wei, Chao; Liu, Zhao-Jun; Li, Zeng-Yao, Qu, Zhi-Guo; He, Ya-Ling; Tao, Wen-Quan. Numerical study on some improvements in the passive cooling system of a radio base station base on multiscale thermal modeling methodology-Part I: confirmation of simplified models. Numerical Heat Transfer, Part A: Applications, Vol. 65, No. 9, P. 844-862, 2014. DOI: $10.1080 / 10407782.20$ 13.826082 .

11. Семена, М.Г.; Гершуни, А.Н.; Зарипов, В.К. Тепловые трубы с металловолокнистыми капиллярными структурами. К.: Выща школа, 1984. 216 с.

12. Chen, Xianping; Ye, Huaiyu; Fan, Xuejun; Ren, Tianling; Zhang, Guoqi. A review of small heat pipes for electronics. Applied Thermal Engineering, Vol. 96, No. 5, P. 1-17, 2016. DOI: 10.1016/j.applthermaleng.2015.11. $\underline{048}$. 